\title{
A new Allocyclops (Crustacea, Copepoda, Cyclopoida) from bromeliads and records of freshwater copepods from Mexico
}

\author{
Eduardo SUÁREZ-MORALES \\ El Colegio de la Frontera Sur (ECOSUR), Unidad Chetumal, \\ Chetumal, Quintana Roo 77014 (Mexico) \\ esuarez@ecosur.mx
}

Fredy MENDOZA Departamento de Control de Enfermedades Transmitidas por Vector, Servicios de Salud del Estado de Veracruz, Jalapa, Veracruz (Mexico)

Nancy MERCADO-SALAS

El Colegio de la Frontera Sur (ECOSUR), Unidad Chetumal, Chetumal, Quintana Roo 77014 (Mexico)

KEY WORDS

Crustacea, Copepoda, microcrustaceans,

Bromeliaceae, freshwater, Mexico, new species.
Suárez-Morales E., Mendoza F. \& Mercado-Salas N. 2010. - A new Allocyclops (Crustacea, Copepoda, Cyclopoida) from bromeliads and records of freshwater copepods from Mexico. Zoosystema 32 (3): 393-407.

\section{ABSTRACT}

The cyclopoid copepod fauna of freshwater systems of the Mexican state of Veracruz, on the Gulf coast of Mexico, was completely unknown. During routine surveillance for larval mosquitoes, several types of aquatic habitats, including ephemeral ponds, springs, and bromeliads, were sampled and cyclopoid copepods were taxonomically studied. Five species were identified, among them a new species of the cyclopine genus Allocyclops Kiefer, 1932. This species, collected from the bromeliad Tillandsia heterophylla Morren, 1873, resembles A. excellens Kiefer, 1956, A. consensus Karanovic, 2003, and A. silvaticus Rocha \& Björnberg, 1988 , but it can be easily distinguished by its strong, ornamented anal operculum and the shape of the genital double somite, among other characters. The new species is tentatively assigned to the subgenus Psammocyclops sensu Karanovic by having an exopodal seta on the antenna, but it is clear that the subgeneric limits should be revised with a complete set of characters. The genus has not been hitherto found from bromeliads. This is also the first record of Allocyclops in continental North America and the first records of freshwater cyclopoid copepods from this part of Mexico. 


\section{MOTS CLÉS \\ Crustacea, \\ Copepoda, \\ microcrustacées, \\ Bromeliaceae, \\ eau douce, copepods, \\ Mexique, \\ espèce nouvelle.}

\section{RÉSUMÉ}

Un nouvel Allocyclops (Crustacea, Copepoda, Cyclopoida) vivant dans les broméliacées et mention de copépodes d'eau donce du Mexique.

La faune de copépodes cyclopoïdes des systèmes d'eau douce de l'état mexicain de Veracruz, sur la côte du Golfe du Mexique, était complètement inconnue. Lors d'opération de surveillance des larves de moustiques, plusieurs types d'habitats aquatiques, dont des mares temporaires, des sources et des Bromeliaceae, ont été échantillonnés et les copépodes cyclopoïdes ont été étudiés taxonomiquement. Cinq espèces ont été identifiées, parmi lesquelles une nouvelle espèce du genre Allocyclops Kiefer, 1932 (Cyclopinae). Cette espèce, récoltée dans la Bromeliaceae Tillandsia heterophylla Morren, ressemble à A. excellens Kiefer, 1956, A. consensus Karanovic, 2003, et $A$. silvaticus Rocha \& Björnberg, 1988, mais s'en distingue facilement par son opercule anal fort et ornementé et par la forme du double somite génital, entre autres caractères. La nouvelle espèce est provisoirement attribuée au sous-genre Psammocyclops sensu Karanovic du fait de la présence d'une soie exopodale sur l'antenne, mais les limites subgénériques doivent être révisée avec un jeu complet de caractères. Ce genre n'avait pas encore été trouvé dans des Bromeliaceae. C'est aussi la première mention d'Allocyclops d'Amérique du Nord continentale et les premières mentions de copépodes cyclopoïdes d'eau douce de cette partie du Mexique.

\section{INTRODUCTION}

A series of biological surveys of the mosquito fauna of freshwater systems of the Mexican state of Veracruz, on the western coast of the Gulf of Mexico, was developed during several years (Mendoza 2007). These studies aimed to develop an inventory of mosquitoes and their habitats in the region, which comprises different hydrological basins and a wide variety of aquatic habitats suitable for larval mosquitoes. We obtained samples from different aquatic environments including ephemeral ponds, small reservoirs, and bromeliads. Freshwater cyclopoid copepods have not been hitherto surveyed in Veracruz; in fact, there is only a single record of the widespread diaptomid calanoid Mastigodiaptomus albuquerquensis (Herrick, 1895) (Suárez-Morales \& Reid 1998).

Based on these primarily entomological collections, cyclopoid copepods were taxonomically studied to provide the first records of this group from this Mexican state. Previous national and regional records of each species recorded are provided together with comments on their distribution and potential for mosquito control. Bromeliads are also habitats for mosquito larvae and for other invertebrates including copepods (Reid 1986); in one of the localities sampled, several male and female specimens of an undescribed cyclopine cyclopoid were collected from the water deposit in the bromeliad. These specimens were found to belong to the genus Allocyclops Kiefer, 1932; the new species is described in full and compared with its known congeners.

\section{MATERIALS AND METHODS}

The copepods examined during this survey were collected incidentally during routine biological surveillance for larval mosquitoes conducted by the Vector Department of the Health Ministry of the state of Veracruz (Mendoza 2007). Samples were obtained from different freshwater habitats in the northern region of Veracruz. Biological samples were obtained from ephemeral springs, ponds, natural lakes, and bromeliads at different times during 2007 and 2008. Samples of water were 
collected by using hand-towed plankton nets and pipettes in the potential mosquito habitats examined. Samples were fixed and preserved in formalin and then transferred to $70 \%$ ethanol for preservation. Copepods were sorted out and maintained in 70\% ethanol with a drop of glycerine. Specimens were dissected and examined taxonomically following the techniques described by Williamson \& Reid (2001). All dissected specimens and appendages were mounted in semi-permanent slides with glycerine sealed with Entellan ${ }^{\circledast}$ or nail varnish. Some adult specimens of the new species were processed for SEM analysis; observations were made using a JEOL LV-5900 microscope at the Universidad Autónoma de Aguascalientes, Mexico. The specimens were deposited in the collection of zooplankton held at El Colegio de la Frontera Sur (ECO-CHZ), Chetumal, Mexico, and in the Muséum national d'Histoire naturelle, Paris (MNHN).

\section{SYSTEMATICS}

Order CYCLOPOIDA G. O. Sars, 1886 Family CyCLOPIDAE Rafinesque, 1815 Subfamily EucyclopinaE Kiefer, 1927 Genus Macrocyclops Claus, 1893

\section{Macrocyclops albidus (Jurine, 1820)}

Material eXamined. - Mexico. El Castillo, Jalapa, Veracruz (1932'45”N, 96'51'44”W), altitude $1140 \mathrm{~m}$, 18.IX.2007, Ruth Hernández Xoliot, 8 adult $\$$ \% , 2 copepodites (ECO-CHZ-05502).

\section{REMARKS}

This widespread species has been recorded from different habitats; very common in North America (Williamson \& Reid 2001). In Mexico it has been reported from Aguascalientes, Campeche, Chiapas, Coahuila, Distrito Federal, Guerrero, Mexico, Michoacán, Nuevo León, Quintana Roo, San Luis Potosí, Tabasco and Yucatan (Suárez-Morales \& Reid 1998). Because of its large size and predating behaviour, it has been advanced as a potentially useful species for mosquito control in tropical and subtropical America (Rawlins et al. 1997; Rey et al. 2004; Suárez-Delgado et al. 2005).

\section{Subfamily Cyclopinae Rafinesque, 1815 \\ Genus Mesocyclops Sars, 1914}

Mesocyclops longisetus s.s. (Thiébaud, 1912)

Material eXamined. - Mexico. El Castillo, Jalapa, Veracruz (19³2'45”N, 9651'44”W), 18.IX.2007, Ruth Hernández Xoliot, 3 adult $\uparrow \%, 2$ copepodites (ECO-CHZ-05503).

\section{REMARKS}

The strict form of this species appears to have a neotropical distribution; it has been known to occur in Brazil, Argentina, Paraguay, Peru, Colombia, Chile, Honduras, Panama, southern United States, and Caribbean islands (Pilati \& Menu-Marque 2002; Dussart \& Defaye 2006). In Mexico it has been recorded only from states in the southeast: Campeche, Chiapas, Mexico, Tabasco, and Yucatan (Gutiérrez-Aguirre \& Suárez-Morales 2001; Gutiérrez-Aguirre et al. 2006). Because of its size, mandibular morphology and its effectiveness in predating larval mosquitoes (Suárez-Morales et al. 2003), this species has become one of the main candidates to develop local strategies for biological control of mosquitoes in Mexico. This has also been observed by Pernía et al. (2007) in Venezuela, where this copepod species was evaluated as a biological control of larval stages of Anopheles together with its congener $M$. meridianus Kiefer, 1926. Both species of Mesocyclops were shown to have a similar predatory potential.

\section{Genus Acanthocyclops Kiefer, 1927}

\section{Acanthocyclops robustus (Sars, 1863)}

Material examined. - Mexico. El Castillo, Jalapa, Veracruz (19³2'45”N, 9651'44”W), 18.IX.2007, Ruth Hernández Xoliot, 2 adult $\uparrow \%, 30^{\circ} 0^{\prime \prime}$, several copepodites (ECO-CHZ-05504).

\section{REMARKS}

This is a widespread species that has been taxonomically studied in detail because of its high morphological and genetic variability (Dodson et al. 2003). Recently, Mercado-Salas et al. (2009) found two undescribed species from central Mexico 
that belong to the robustus-vernalis complex, thus supporting the notion that the diversity of the genus in Mexico is probably underestimated. Previous records of this species in Mexico include: Distrito Federal, Mexico, Nuevo León, Puebla, San Luis Potosí and Aguascalientes. Acanthocyclops robustus has been studied as an important and highly competent intermediate host of the fungus Coelomomyces infecting populations of mosquito larvae (Apperson et al. 1992). The predatory potential of this species and of its closest congener $A$. vernalis (Fischer, 1853) appears to be lower than that observed for species of Mesocyclops; they prey on mosquito larvae but not as consistently as expected in a biological control (Marten et al. 1994).

Genus Allocyclops Kiefer, 1932

(sensu Karanovic 2001)

Allocyclops veracruzanus $\mathrm{n}$. sp.

(Figs 1-6)

Type Material. - Mexico. Holotype: Rancho Viejo, near San Andrés Tlalnehuayocan, central sector of the state of Veracruz, altitude $1420 \mathrm{~m}$, from the widespread bromeliad Tillandsia heterophylla Morren, 7.VII. 2008, Fredy Mendoza, adult $\%$, dissected, mounted in glycerine sealed with Entellan ${ }^{\bullet}$ (ECO-CHZ-03953).

Allotype: same date, site, and collector as holotype, 1 dissected adult $0^{\prime \prime}$, mounted in glycerine, slide sealed with Entellan ${ }^{\circ}$ (ECO-CHZ-03954).

Paratypes: same date, site, and collector as holotype, 1 dissected adult $\%$, mounted in glycerine, slide sealed with Entellan ${ }^{\circ}$ (ECO-CHZ-03955); 1 dissected 9 mounted in glycerine, slide sealed with Entellan (MNHN-Cp6031); 1 dissected $0^{7}$ mounted in glycerine, slide sealed with Entellan ${ }^{\circledR}$ (MNHN-Cp6032). - Same locality and date, 4 undissected adult $\$$ \% , ethanol-preserved; 2 undissected adult $0^{\prime \prime} \sigma^{\circ}$, ethanol-preserved (ECO-CHZ-03955).

Additional specimens: $1 \%$ and $1 O^{7}$ specimens processed for observation by SEM at Universidad Autónoma de Aguascalientes. Several copepodites in original sample.

TYPE LOCALITY. - Rancho Viejo, San Andrés Tlalnehuayocan $\left(19^{\circ} 32^{\prime} 22^{\prime \prime N}, 97^{\circ} 00^{\prime} 50^{\prime \prime} \mathrm{W}\right)$, Veracruz, Mexico.

ETYMology. - The specific epithet makes reference to Veracruz (meaning "true cross"), the name of the Mexican state in which these specimens were collected.

DIAGNOSIS. — Small, compact body, harpacticoid-shaped. Body without pseudosomite between fifth pediger and genital double somite. Female genital double somite slightly wider than long. Female leg 6 plate on caudal end of proximal third of somite. Anal somite with well-developed anal operculum, triangular, coarsely serrate. Caudal rami short, medialmost and lateralmost terminal setae with breaking planes. Antennule with 11 segments in the female, 15 in the male; segment 7 with three setae, median caudal seta present on the ultimate antennular segment. Antennal basis with exopodal seta. Mandibular palp reduced, with single short seta. Rami of swimming legs 1-4 broad, endopodites and exopodites two-segmented. Endopodite of male leg 3 lacking modified setae. Spine formula 3, 4, 4, 3 in both females and males. Leg 5 composed of proximal segment completely fused to bearing pedigerous somite, armed with a single distal seta; terminal segment also fused, with two equal terminal setae. Leg 6 of male represented by plate with two short, stout setae.

\section{DESCRIPTION \\ Female}

Total body length $=0.55 \mathrm{~mm} \pm 0.03 \mathrm{~mm}(\mathrm{n}=4)$ from anterior end of cephalothorax to posterior margin of anal somite. Body elongate, with harpacticoid shape, cephalothorax relatively long, slightly expanded laterally at midlength of cephalosome in dorsal view; lateral margins of pedigers 3 and 4 straight (Figs 1A; 5A). Cephalothorax length = $0.38 \pm 0.06 \mathrm{~mm}(\mathrm{n}=4)$, representing almost $70 \%$ of total body length. Body surface smooth, antennules short, not reaching anterior margin of first pediger. Rostrum short, triangular; labrum armed with 8 blunt central teeth between weakly produced rounded lateral corners, plus two rows of setules on frontal surface (Fig. 5B). Urosome formed by four somites, genital somite, two free somites and anal somite; relative ratio of each as: $58: 12.8: 15.2: 14=$ 100. Genital double-somite broader than long, with smooth dorsal and ventral surfaces, lateral margins rounded, strongly expanded; distal margin of genital double-somite and two succeeding urosomites with irregularly serrate hyaline membrane (Figs 2E; $5 \mathrm{E}, \mathrm{F})$. Anal somite relatively large, with posterior margin armed with short spines; anal operculum subtriangular, with coarsely serrate posterior margin, operculum produced to distal third of caudal ramus (Figs 1B; 2E). Caudal ramus about two times longer than broad, ornamented with strong spines along entire distal margin. Lateral seta inserted at about midlength of ramus dorsally; dorsal seta about as 


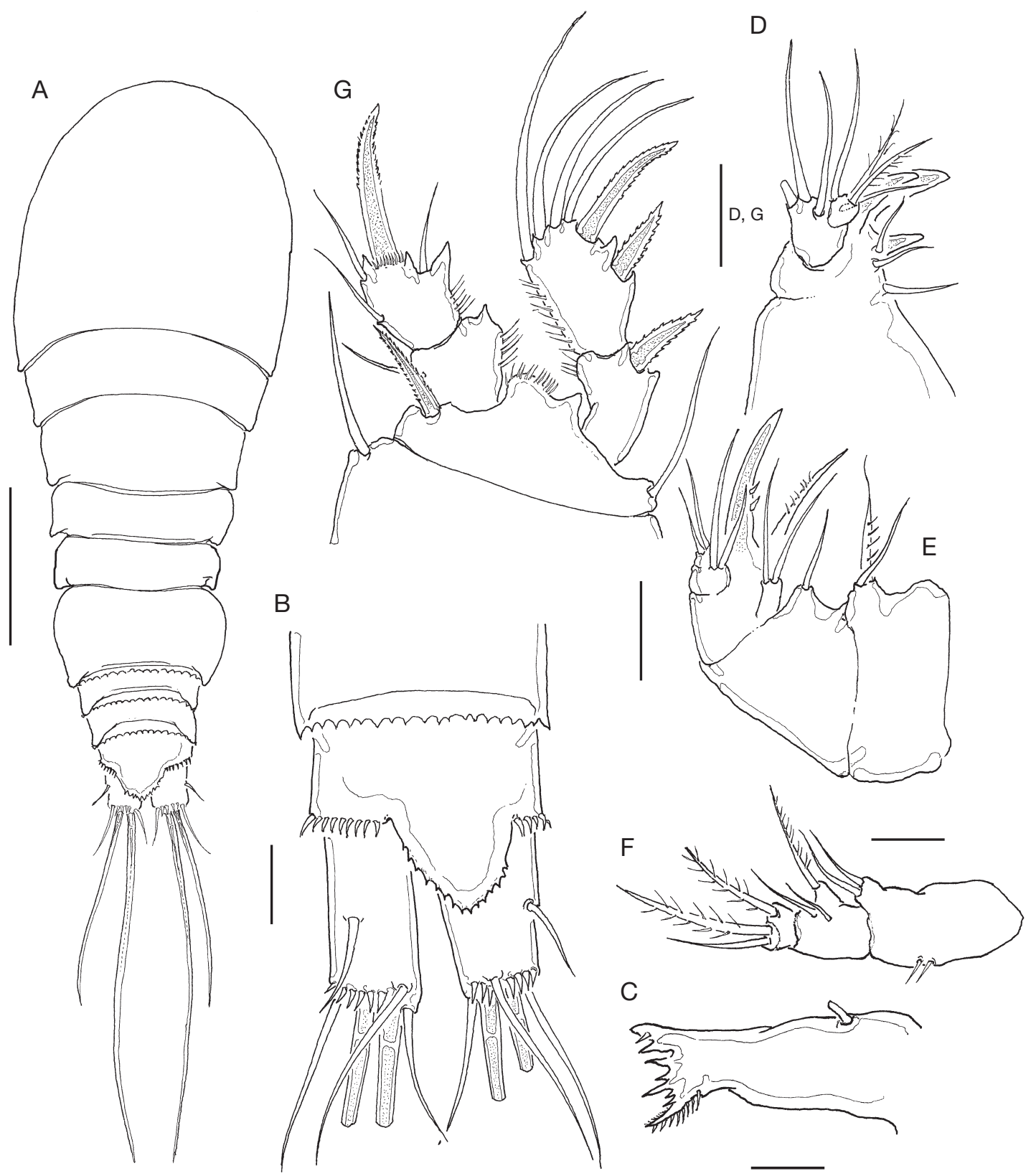

FIG. 1. - Allocyclops veracruzanus n. sp., holotype from Veracruz, Mexico (ECO-CHZ-03953): A, habitus, dorsal view; B, anal somite and caudal rami, dorsal; C, mandible; D, maxillule; E, maxilla; F, maxilliped; G, leg 1. Scale bars: A, $100 \mu \mathrm{m} ; \mathrm{B}-\mathrm{G}, 10 \mu \mathrm{m}$.

long as ramus. Lateralmost terminal seta about as long as dorsal seta. Middle terminal setae with proximal breaking planes (Fig. 1B).
Antennule (Fig. 3A). 11-segmented, armament per segment as follows (s, seta; sp, spine; ae, aesthetasc): 1(8s), 2(2s), 3(5s), 4(1s), 5(sp), 6(2s), 7(3s), 8(2s), 
TABLE 1. - Armament of legs 1-4 of female Allocyclops veracruzanus n. sp., from Veracruz, Mexico. Roman numerals indicate spines; Arabic numerals indicate number of setae. Sequence of pattern: inner-outer.

\begin{tabular}{lcccc}
\hline & Coxa & Basipod & Exopod & Endopod \\
\hline Leg 1 & $1-0$ & $1-I$ & $0-I ; 2,2, I I$ & $1-0 ; 2, I, 1$ \\
Leg 2 & $1-0$ & $0-1$ & $0-I ; 2,2$, III & $1-0 ; 2,1, I, 1$ \\
Leg 3 & $1-0$ & $0-1$ & $0-I ; 2,2$, III & $1-0 ; 2,1$, II \\
Leg 4 & $1-0$ & $0-1$ & $0-I ;$ II,3 & $1-0 ; 2, I, 1$ \\
\hline
\end{tabular}

$9(2 s), 10(2 s), 11(7 s+1 a e)$. Terminal segments without hyaline membrane.

Antenna (Figs 2A; 6B). Four-segmented, basis with one seta on anterior corner and another seta on middle distal margin; exopodal seta present. First endopodal segment with single seta; second segment with four setae. Third endopodal segment with 7 distal setae; inner margin with row of spinules on second and third segments.

Mandible (Fig. 1C). Gnathobase with 6 strongly chitinized teeth; 3 ventral teeth bicuspidal, blunt, three dorsal ones acute. Palp reduced, with one short socketed seta.

Maxillule (Figs 1D; 5C). Precoxal arthrite armed with 3 strong chitinized claws and 3 setae on frontal side. Maxillular palp 2-segmented, with 4 subequal setae on proximal article, plus 3 terminal shorter setae, differently armed, on short distal article.

Maxilla (Figs 1E; 5C). Precoxa and coxa unfused; precoxal endite armed with two plumose setae. Coxa with single seta on middle inner margin; coxal caudal surface naked. Proximal basipodal endite with 2 apical setae. Claw-like basal endite bearing 2 or 3 teeth along inner margin. Endopod 2-segmented, each with 2 setae.

Maxilliped (Figs 1F; 5C). Four-segmented. Coxa with two short, strong setae in distal position; pair of unsocketed spinules on middle surface of coxa. Basis with 3 setae, without basal ornamentation. Endopod 2-segmented, first segment with single, stout basal spine furnished spinules. Second endopod reduced, apical, armed with 2 subequal setae, 1 plumose.

Leg 1 (Figs 1G; 5D). Intercoxal sclerite (coupler) with convex rounded projections, surface naked. Coxa with strong inner coxal seta. Basis with slender seta on outer margin; inner margin with strong, pinnate spiniform basipodal seta reaching about midlength of second endopodal segment. Endopod and exopod 2-segmented. Armature as in Table 1.

Leg 2 (Fig. 2B). Intercoxal sclerite (coupler) and coxa as in leg 1 . Basis with slender basipodal seta on outer margin, row of spinules at insertion of seta. Distal margin with moderate disto-medial expansion and row of spines between insertion point of exopod and endopod. Endopod and exopod 2-segmented. Armature as in Table 1.

Leg 3 (Fig. 2C). Intercoxal sclerite and coxa as in leg 1. Basis as in leg 2. Endopod and exopod 3-segmented; inner margin of exopodal segments with hair-like ornamentation; first exopod with distal row of spinules. Armature as in Table 1.

Leg 4 (Fig. 2D). Intercoxal sclerite as in legs 1-3. Coxa with strong inner coxal seta, outer margin with row of long, strong spines; additional row of small spines along distal margin. Basis with slender basipodal seta and row of strong spines on outer margin; distal margin with moderate disto-medial expansion armed with row of spines. Endopod and exopod 2-segmented. Endopod longer than exopod. Armature as in Table 1. Outer margins of exopodal segments with hair-like ornamentation; first exopodal segment with row of spines on distal margin.

Leg 5 (Fig. 2E). Proximal segment fused to somite armed with single, relatively long seta; distal segment fused, with 2 terminal setae equal in length.

Leg 6 (Fig. 2E). Broad plate located in middle caudal position, near lateral margin of genital somite with laterally directed short dorsal seta and 2 tiny lateral spinules. 


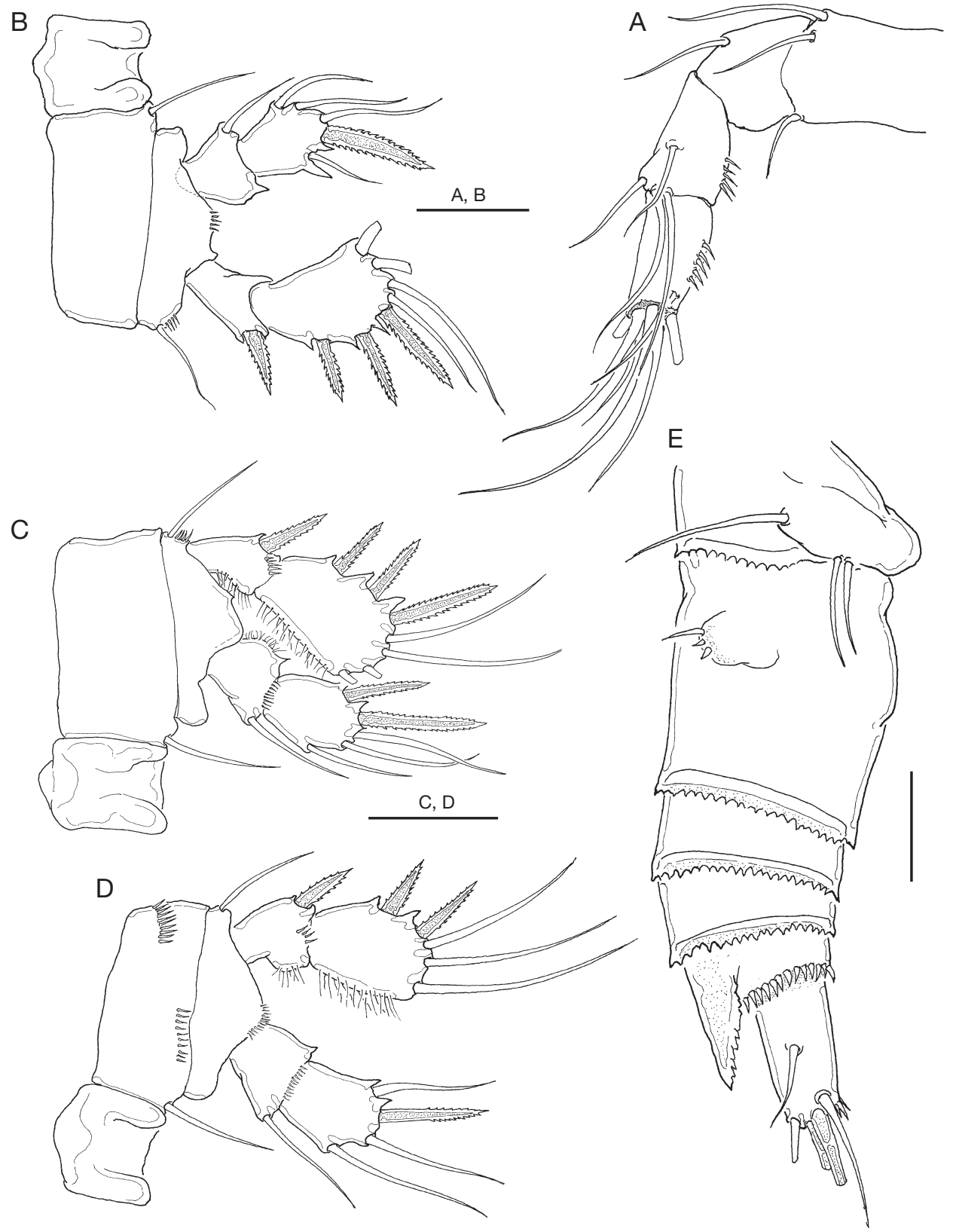

FIG. 2. - Allocyclops veracruzanus n. sp., o holotype from Veracruz, Mexico (ECO-CHZ-03953): A, antenna; B, leg 2; C, leg 3; D, leg 4; E, urosome, lateral. Scale bars: A-D, $10 \mu \mathrm{m}$; E, $20 \mu \mathrm{m}$.

Male (Fig. 6A)

Body robust, without hairs or pits on dorsal surface. Smaller, slightly slenderer than female. Total body length of allotype specimen $=0.50 \mathrm{~mm}$, cephalothorax length $=0.32 \mathrm{~mm}$, representing almost $64 \%$ of total body length. Length of additional male: $0.52 \mathrm{~mm}$, cephalothorax: $0.34 \mathrm{~mm}$. Body and appendages as in females except for sexual dimorphism. 
Antennule (Figs 3B; 6C). Geniculate, 15-segmented.

Legs 1, 2 (Fig. 4A, B). As in female.

Leg 3 (Fig. 4C). Second endopodal segment with additional seta on outer margin ( 4 vs 3 in the female), simple seta instead of spiniform serrate seta in female on inner margin of same segment. Distal endopodal seta unmodified.

Leg 4 (Fig. 4D). As in female.

Leg 6 (Figs 3C; 6D). Plate with one long medial stout spiniform, biseri ally serrate seta and a normal seta reaching midlength of succeeding posterior urosomite.

Urosome (Fig. 6E). 5-segmented, genital somite largest of urosome; relative lengths of urosomites as: $35.8: 23.8: 23: 10: 7.4=100$. Ventral and dorsal surface of anal somite smooth; distal margin with continuous dorsoventral row of spines. Anal operculum subtriangular, with coarsely serrate posterior margin, operculum relatively shorter than in female, produced to proximal third of caudal ramus. Caudal rami slightly shorter than in female, 1.85 times longer than wide, ornamented with strong spines along distal margin. Dorsal seta shorter than ramus, about 0.8 times its length. Lateralmost terminal seta longer than dorsal seta.

\section{REMARKS}

Following the criteria by Reid (1988), Rocha \& Björnberg (1988), and the revision of the genus by Karanovic (2001), this species was included in Allocyclops s.l. by its possession of several diagnostic characters of the genus including a genital somite broader than long, 11-segmented antennules, exopodal seta present on the antenna, reduced antennal setation, anal operculum slightly longer than anal somite, fifth leg completely fused to somite, mandibular palp reduced to a short seta, legs 1-4 with 2-segmented rami, a spine formula of $3,4,4,3$, inner coxal and basipodal setae present on legs 1-4. The male endopod of leg 3 lacks modified spines or setae. Members of Allocyclops have both the proximal and distal segments of the fifth leg completely fused with the somite, thus diverging from many other similar genera in which the distal segment is represented by a free segment (see Reid \& Ishida 2000). Particularly, the strong development of the anal operculum and the harpacticoid form of the body resembles the pattern found in Speocyclops Kiefer, 1937, in which legs 1-4 have 2-segmented rami, the fifth legs have a variable degree of fusion with the somite, the anal operculum is well developed, and the males lack modified setae or spines on the leg 3 endopod (Reid 1988). However, this Old World genus seems to be restricted to groundwaters of Europe and the Ponto-Caspian region. The only species of the recently erected genus Itocyclops Reid \& Ishida, 2000, I. yezoensis (Itô, 1953), shares several characters with our species, including the shape of the body, the produced anal operculum, and the presence of spines on the distal margin of the caudal rami. Differing from the characters found in our specimens, the distal segment of the fifth leg is free in I. yezoensis, but it also differs in the spine formula of the exopod $(3,4,3,3$ vs $3,4,4,3)$, the segmentation pattern of legs $1-4$, and the presence of a modified spine on the male leg 3 endopod. The genus Yansacyclops Reid, 1988 shares with our species the segmentation of the legs 1-4, the spine formula, the possession of completely fused fifth legs, and unmodified endopod of male leg 3 . There are several characters in the new species that diverge from the Yansacyclops pattern, including the different body shape (clearly cyclopoid in Yansacyclops), the presence of an exopodal antennal seta (absent in the new species), the size of the caudal rami (shorter in the new species), and the development of the anal operculum (weak in Yansacyclops) (see Reid 1988).

According to the taxonomic arrangement proposed by Karanovic (2001), this species could be placed in the subgenus Psammocyclops by the presence of an exopodal seta on the antennal basis, and the second endopodal segment of leg 4 armed with 2 inner setae, 1 apical spine, and 1 outer seta. There are only four species currently included in this subgenus, Allocyclops (P.) excellens (Kiefer, 1955), A. (P.) silvaticus Rocha \& Björnberg (1988), A. (P.) transsaharicus (Lamoot, Dumont \& Pensaert, 1981), and 


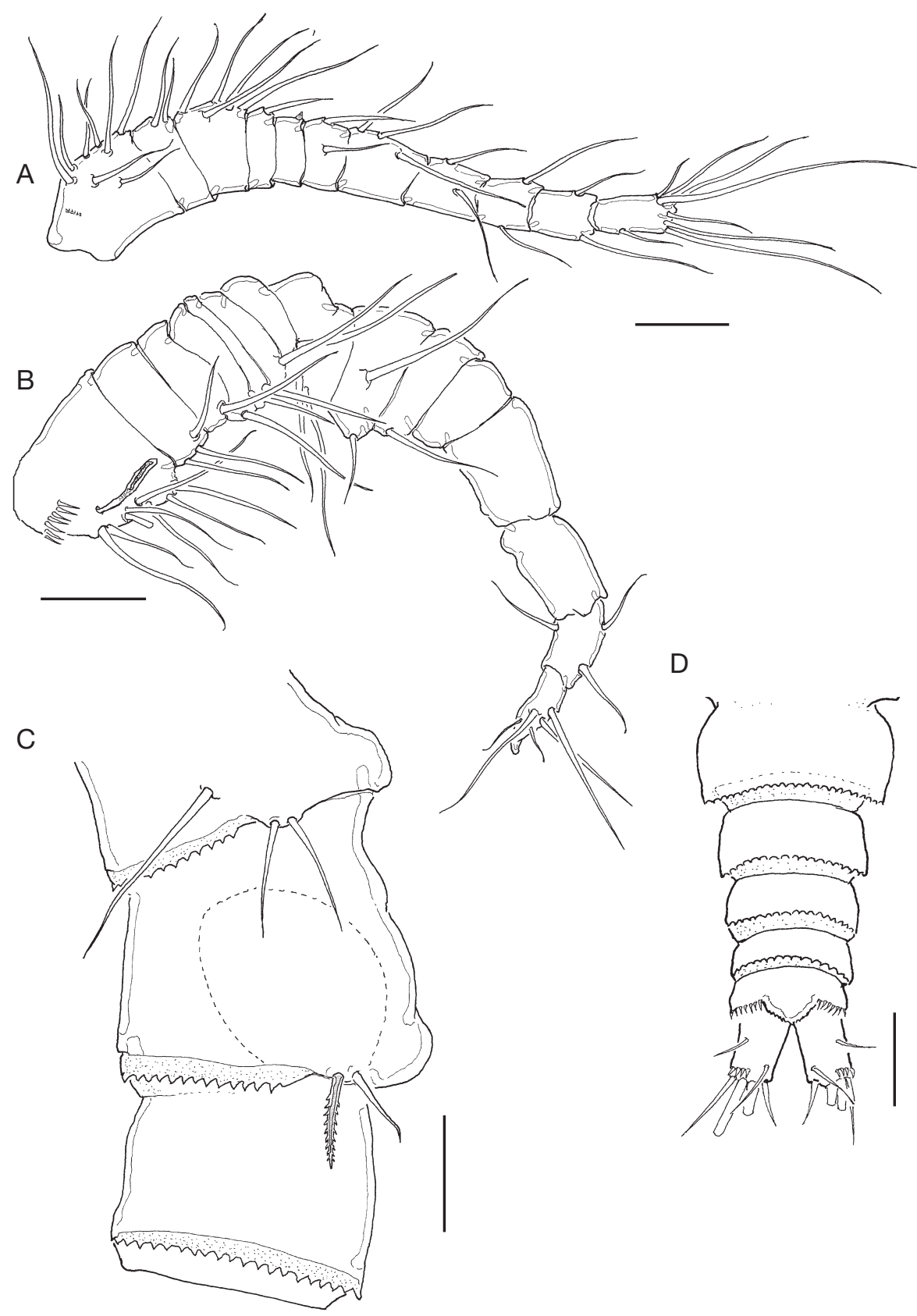

FIG. 3. - Allocyclops veracruzanus n. sp., from Veracruz, Mexico: A, antennule; B, antennule; C, fifth pedigerous and first urosomal somites, lateral; D, urosome, dorsal view; A, o holotype (ECO-CHZ-03953); B-D, ơ allotype (ECO-CHZ-03954). Scale bars: 20 $\mu \mathrm{m}$.

A. (P.) consensus Karanovic, 2003 (Karanovic 2001; Dussart \& Defaye 2006). However, our specimens have a two-segmented maxillular palp, a character that diverges from the one-segmented condition stated by Karanovic (2001) as a feature to recognize this subgenus. In the subsequent description of $A$. consensus 
A

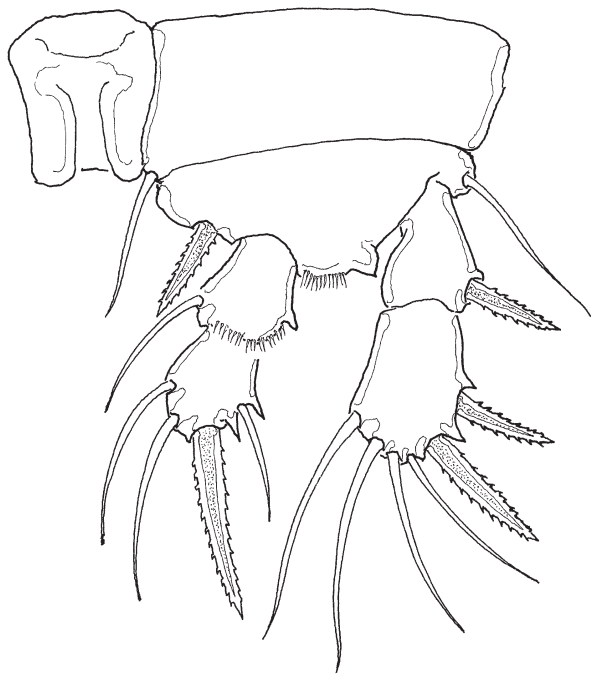

C

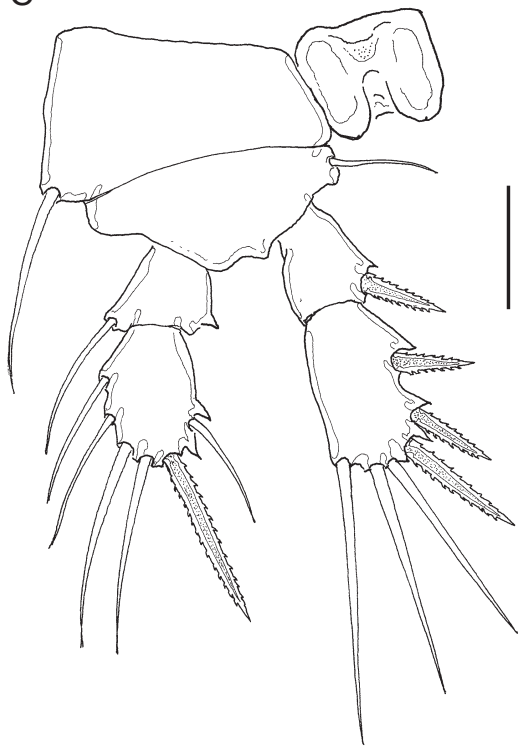

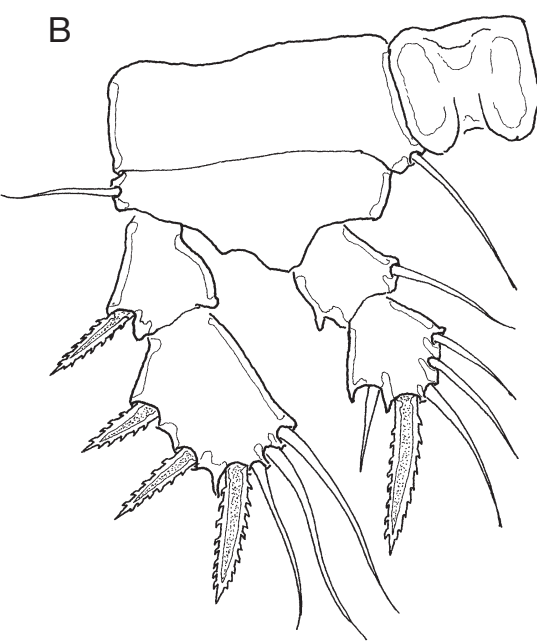

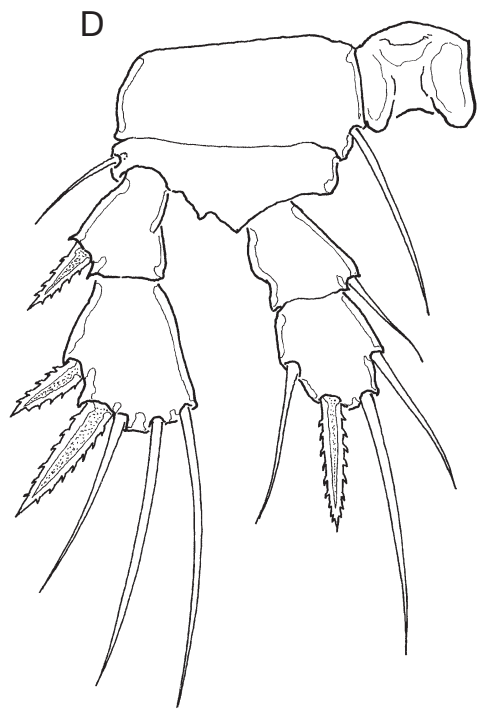

FIG. 4. - Allocyclops veracruzanus n. sp., ơ allotype from Veracruz, Mexico (ECO-CHZ-03954): A, leg 1; B, leg 2; C, leg 3; D, leg 4. Scale bars: 10 m.

Karanovic, 2003, the author placed this species in the subgenus Psammocyclops despite the fact that it has a two-segmented maxillular palp (see Karanovic 2003). Apparently, this is not a reliable character and should be discarded from the subgeneric diagnosis of Psammocyclops; only in such circumstance could the new species be assigned to this subgenus. Hence, the only relatively strong character to distinguish Psammocyclops from the other subgenera could be the presence of an exopodal seta on the antenna. The genus and its proposed subgeneric division should be revised with a complete set of data on the armature of the mandibles and maxillules, such information is not available for many species. 

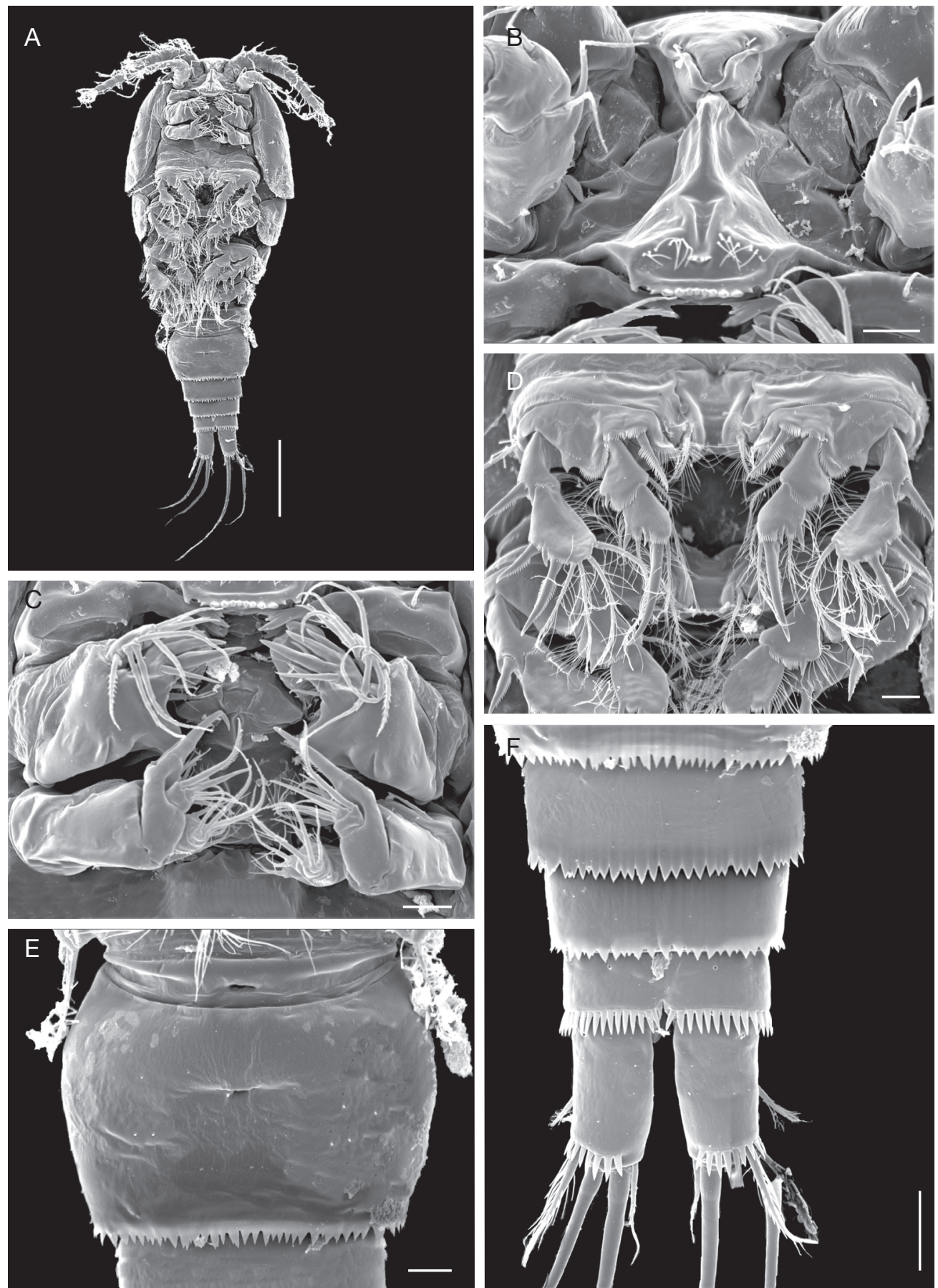

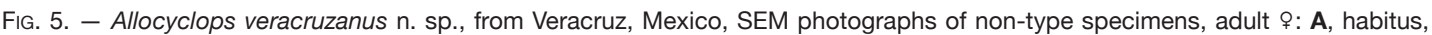
ventral view; B, rostral field and labrum, ventral view; C, mouthparts including maxillules, maxillae and maxillipeds, ventral view; D, first swimming legs, ventral view; E, genital double somite, ventral; F, urosomal somites and caudal rami, ventral view. Scale bars: A, $100 \mu \mathrm{m} ; \mathrm{B}-\mathrm{E}, 10 \mu \mathrm{m} ; \mathrm{F}, 20 \mu \mathrm{m}$. 
Following Karanovic (2001, 2003), the Mexican specimens key out to $A$. excellens Kiefer, 1955 by the presence of one apical spine and two inner setae on the second endopodal segment of leg 4, all swimming legs with an inner coxal seta, and a 2,3,3,2 spine formula of the second exopodal segments. There are several characters useful to distinguish $A$. veracruzanus $\mathrm{n}$. sp. from $A$. excellens; in the former the setal elements of the fourth leg endopod are relatively shorter than in A. excellens, in which these setae are almost twice as long as the distal spine. In $A$. excellens the anal operculum is moderately developed, whereas this structure is clearly stronger in the new species; also, the caudal rami are clearly shorter in the new species (length/ width ratio $=1.8)$ than in $A$. excellens, with slenderer rami (length/width ratio $=2.4$ ). The shape and proportions of the genital somite and also the ornamentation of the urosomites (crenulated in the new species, smooth in $A$. excellens) are clearly different in these species (see Kiefer 1955). The male sixth leg differs in both species, in $A$. excellens it is represented by a plate armed with three short, subequal setae, whereas in the new species it has two relatively long, stout setae, as in $A$. silvaticus (see Rocha \& Björnberg 1988). The new species also resembles $A$. consensus by its sharing of the same general characters, including a short exopodal seta on the antenna and a 2-segmented maxillular palp (Karanovic 2003), but it differs from the new species in the spine formula of the second exopodal segments: 2,3,3,2 in the new species vs 2,2,2,2 in A. consensus. Also, the female genital double somite is different in both species, wider than long in $A$. veracruzanus $\mathrm{n}$. sp. and the opposite condition is present in $A$. consensus. Also, the posterior margin of the anal operculum is smooth and rounded in A. consensus, whereas it is serrate and subtriangular in the new species.

The new species differs from $A$. silvaticus, the only other known American member of this subgenus, in the size and ornamentation of the anal operculum, which is reduced and naked in $A$. silvaticus, and in the shape of the genital double somite, with straight lateral margins in $A$. silvaticus vs rounded margins in $A$. veracruzanus n. sp. Also, the coxal plates of legs 3 and 4 are armed with rows of spines in A. silvaticus and they are smooth in $A$. veracruzanus n. sp.; further, the fourth leg endopod has 3 outer setae in $A$. silvaticus and only 2 setae are present in the new species (see Rocha \& Björnberg 1988). The other American member of Allocyclops, A. botosaneanui Pleşa, 1981 from Cuba, has a short, quadrate anal operculum, a mandibular palp with one short and two plumose setae, and has other characters diagnostic of the subgenus Allocyclops sensu Karanovic (2001), thus differing from the pattern present in the new species.

\section{DISCUSSION}

The description of $A$. botosaneanui from a cave in Cuba (Pleşa 1981) represented the first record of a species of Allocyclops from the Neotropical region. Later on, Rocha \& Björnberg (1988) described A. silvaticus from Brazil; it was the first representative of the genus in South America, because A. neotropicalis Dussart, 1984 from the Orinoco River in Venezuela, was transferred to the genus Yansacyclops by Reid (1988). Hence, the new species represents the third record of Allocyclops in the neotropics and the first in continental North America.

There are only a few studies on the Neotropical copepod fauna associated to bromeliads and records exist from different geographic areas. The cosmopolitan harpacticoid Phyllognathopus viguieri (Maupas, 1892) and the cyclopoids Ectocyclops phaleratus (Koch, 1838) and Tropocyclops jamaicensis Reid \& Janetzky, 1996 were reported from Jamaica (Janetzky et al. 1996; Reid \& Janetzky 1996). The cyclopine Bryocyclops anninae (Menzel, 1926) was recorded together with $B$. chappuisi Kiefer, 1928 in Puerto Rican bromeliads. Fimbricyclops jimhensoni Reid, 1993 is known from Puerto Rico, where the species was found together with Tropocyclops prasinus (Fischer, 1860) and the harpacticoids Elaphoidella bidens (Schmeil, 1894) and Elaphoidellopsis sewelli (Chappuis, 1828) (Reid 1993; Reid \& Janetzky 1996). In Brazilian bromeliads most records are of the harpacticoid genus Attheyella Brady, 1880 (Por \& Hadel 1986; Janetzky et al. 1996); Rocha \& Björnberg (1987) recorded Muscocyclops operculatus (Chappuis, 1817) from the Jureia Reserve in 

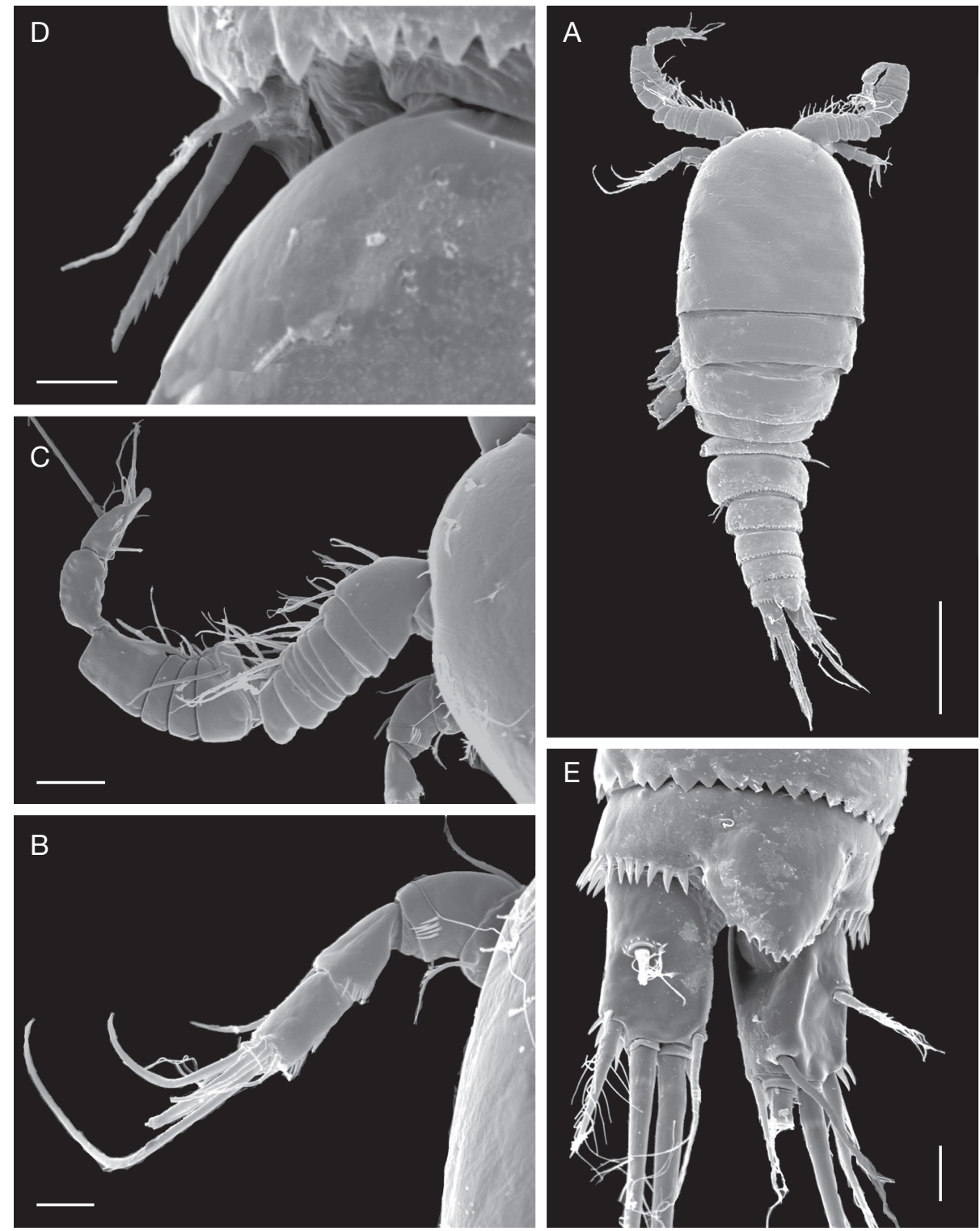

FIG. 6. - Allocyclops veracruzanus n. sp., from Veracruz, Mexico, SEM photographs of non-type specimen, adult ơ: A, habitus, dorsal view; B, antenna, dorsal view; C, antennule, dorsal view; D, vestigial sixth legs; E, anal somite showing anal operculum and caudal rami, dorsal view. Scale bars: A, $100 \mu \mathrm{m}$; B, E, $10 \mu \mathrm{m} ; \mathrm{C}, 20 \mu \mathrm{m} ; \mathrm{D}, 5 \mu \mathrm{m}$.

Sáo Paulo. Overall, the genus Allocyclops appears to have preference to interstitial and groundwater habitats, including caves (Karanovic 2001, 2003); it has not been hitherto recorded from bromeliads. Further, there are no previous records of copepods from bromeliads in continental North America or Mexico (see Suárez-Morales \& Reid 1998, 2003; Williamson \& Reid 2001). The present report of the new species $A$. veracruzanus $\mathrm{n}$. sp. represents not only the first record of a cyclopoid copepod 
from a bromeliad in the region but also the second finding of the genus outside South America, after A. botosaneanui (Pleşa 1981; Rocha \& Björnberg 1987; Karanovic 2001, 2003). It is expected that new collections from these habitats in the area will produce additional new, interesting records of cyclopoid copepods.

\section{Acknowledgements}

This work is part of a project developed by the Servicios de Salud de Veracruz in Jalapa, Veracruz to explore the local copepod fauna as a possible source of agents for mosquito control. Sergio Ibáñez-Bernal (INECOL) and Ruth Hernández Xoliot (SESVER), of the VECTOVER (Vectores de Veracruz) team, and Israel Villa, Carlos García, Mario Vázquez, and Marco Galindo contributed in different aspects to this project. Rosa Maria Hernández Flores (ECOSUR) and Danielle Defaye $(\mathrm{MNHN})$ deposited type specimens of the new species. Specimens of Allocyclops were kindly processed for SEM analysis by Araceli Adabache and Marcelo Silva-Briano (Universidad Autónoma de Aguascalientes). Valuable comments on an earlier version of this manuscript were received from Frank Fiers and from an anonymous reviewer; these are deeply appreciated as they contributed much in improving the quality of this contribution.

\section{REFERENCES}

Apperson C. S., Federici B. A., SteWart W. \& Tarver F. R. 1992. - Evidence for the copepods Acanthocyclops robustus and Mesocyclops edax as competent intermediate hosts for Coelomomyces punctatus during an epizootic in a larval population of the mosquito Anopheles quadrimaculatus. Journal of Invertebrate Pathology 60: 229-236.

DussarT B. H. \& Defaye D. 2006. - World Directory of Crustacea Copepoda. II. Cyclopiformes. Backhuys Publishers, Leiden, 354 p.

Dodson S. I., Grishanin A. K., Gross K. \& WYNGAARD G. A. 2003. - Morphological analysis of some cryptic species in the Acanthocyclops vernalis species complex from North America. Hydrobiologia 500: 131-143.

Gutiérrez-Aguirre M. A. \& SuÁrez-Morales E. 2001. - Distribution and taxonomy of the tropical American Mesocyclops Sars, 1914 (Copepoda, Cyclopoida). Crustaceana 74: 477-487.
Gutiérrez-Aguirre M. A., SuÁrez-Morales E., Cervantes A., Elías-Gutiérrez M. \& Previatelli D. 2006. - The neotropical species of Mesocyclops (Copepoda, Cyclopoida): an upgraded identification key and comments on selected taxa. Journal of Natural History 40: 549-570.

JANETZKy W., Martínez A. \& Reid J. W. 1996. Attheyella (Canthosella) mervini sp. n. (Canthocamptidae, Harpacticoida) from Jamaican bromeliads. Hydrobiologia 339: 123-135.

KaranoviC T. 2001. - Description of Allocyclops montenegrinus, spec. nov. and a revision of the genus Allocyclops Kiefer, 1932. Spixiana 24: 19-27.

KARANOVIC T. 2003. - First representative of the genus Allocyclops Kiefer, 1932 (Crustacea, Copepoda, Cyclopoida) from the Australian subterranean waters. Annales de Limnologie, International Journal of Limnology 39: 141-149.

Kiefer F. 1955. - Neue Cyclopoida Gnathostoma (Crustacea Copepoda) aus Madagascar, II. Cyclopinae. Zoologischer Anzeiger 154: 222-232.

Marten G., Bordes E. \& NGUYen M. 1994. - Use of cyclopoid copepods for mosquito control. Hydrobiologia 292/293: 491-496.

Mendoza F. 2007. - Diversidad y hábitats acuáticos de mosquitos (Diptera: Culicidae) en la región central de Veracruz, México. Doctoral Dissertation. Instituto de Ecología, Veracruz, Mexico, 124 p.

Mercado-Salas N., SuÁrez-Morales E. \& SilvaBRIANO M. 2009. - Two new Acanthocyclops Kiefer, 1927 (Copepoda: Cyclopoida: Cyclopinae) with pilose caudal rami from semi arid areas of Mexico. Zoological Studies 48: 380-393.

Pernía J., Zoppi de Roa E. \& Palacios-Cáceres M. 2007. - Prey-predator relationship between the cyclopoids Mesocyclops longisetus and Mesocyclops meridianus with Anopheles aquasalis larvae. Journal of the American Mosquito Control Association 23 (2): 166-171.

Pilati A. \& Menu-Marque S. 2002. - Morphological comparison of Mesocyclops araucanus Campos et al., 1974, and $M$. longisetus Thiébaud, 1912, and first description of their males. Beaufortia 52: 1-8.

PleşA C. 1981. - Cyclopides (Crustacea, Copepoda) de Cuba. Résultats des expéditions biospéologiques cubano-roumaines à Cuba 3: 17-34.

POR F. D. \& Hadel V. F. 1986. - Two species of Attheyella (Copepoda: Harpacticoidea: Canthocamptidae) from bromeliads of Serra da Jureia (São Paulo, Brazil). Journal of Crustacean Biology 6: 777-788.

RaWlins S. C., Martínez R., Wiltshire S., Clarke D., PrabHaKar P. \& SPINKS M. 1997. - Evaluation of Caribbean strains of Macrocyclops and Mesocyclops (Cyclopoida: Cyclopidae) as biological control tools for the dengue vector Aedes aegypti. Journal of the American Mosquito Control Association 13: 18-23. 
REID J. W. 1986. - Some usually overlooked cryptic copepod habitats. Syllogeus 58: 594-598.

REID J. W. 1988. - Yansacyclops ferrarii, new genus, new species (Copepoda: Cyclopoida) from the Amazon Basin, Brazil. Hydrobiologia 167/168: 429-434.

REID J. W. 1993. - Fimbricyclops jimhensoni, new genus, new species (Copepoda: Cyclopoida: Cyclopidae), from bromeliads in Puerto Rico. Journal of Crustacean Biology 13: 383-392.

ReID J. W. \& Ishida T. 2000. - Itocyclops, a new genus proposed for Speocyclops yezoensis (Copepoda: Cyclopoida: Cyclopidae). Journal of Crustacean Biology 20: 589-596.

ReID J. W. \& JANETZKY W. 1996. - Colonization of Phytothelmata by Tropocyclops jamaicensis sp. $\mathrm{n}$. (Crustacea: Copepoda: Cyclopoida). Invertebrate Biology 115: 305-320.

Rey J. R., O’Connell S., Suárez S., Menéndez Z., Lounibos L. P. \& BYER G. 2004. - Laboratory and field studies of Macrocyclops albidus (Crustacea: Copepoda) for biological control of mosquitoes in artificial containers in a subtropical environment. Journal of Vector Ecology 29: 124-134.

Rocha C. E. F. \& BJörnberg M. H. G. C. 1987. Copepods of the Jureia ecological reserve, State of São Paulo, Brazil. II. The genera Hesperocyclops, Muscocyclops, and Bryocyclops (Copepoda, Cyclopidae).
Hydrobiologia 153: 97-107.

Rocha C. E. F. \& BJÖRnberG M. H. G. C. 1988. Allocyclops silvaticus sp. n. (Copepoda, Cyclopoida, Cyclopidae), the first representative of the genus in South America. Hydrobiologia 167/168: 445-448.

SuÁrez-Delgado S., Rodríguez J., Menéndez Z., Montada D., García I. \& MarquetTi M. 2005. Macrocyclops albidus (Copepoda: Cyclopidae): una nueva alternativa para el control de larvas de mosquitos en Cuba. Revista Cubana de Medicina Tropical 57: 227-229.

Suárez-Morales E. \& Reid J. W. 1998. — An updated list of the free-living freshwater copepods (Crustacea) of Mexico. Southwestern Naturalist 43: 256-265.

SuÁrez-Morales E. \& Reid J.W. 2003. — Updated checklist of the continental copepod fauna of the Yucatan Peninsula, Mexico, with notes on its regional associations. Crustaceana 76: 977-993.

SuÁrez-Morales E., GutiérreZ-Aguirre M.\& ElíasGUTIÉRREZ M. 2003. — Observations on the structure of the mandible edge in some American Mesocyclops (Copepoda: Cyclopidae). Proceedings of the Biological Society of Washington 116: 742-753.

Williamson C. E. \& ReID J. W. 2001. - Copepoda, in ThOrpe J. H. \& Covich A. P. (eds), Ecology and Classification of North American Freshwater Invertebrates. 2nd edition. Academic Press, New York: 915-954. 